\title{
Cytotoxicity of Vitex agnus-castus fruit extract and its major component, casticin, correlates with differentiation status in leukemia cell lines
}

\author{
HIDETOMO KIKUCHI $^{1,2}$, BO YUAN ${ }^{1,5}$, YOSHIO NISHIMURA ${ }^{2}$, MASAHIKO IMAI $^{1}$, RYOTA FURUTANI ${ }^{1}$, \\ SAKI KAMOI $^{1}$, MISAKO SENO ${ }^{1}$, SHIN FUKUSHIMA ${ }^{1}$, SHINGO HAZAMA ${ }^{1}$, CHIEKO HIROBE ${ }^{3}$, \\ KUNIO OHYAMA $^{1}$, XIAO-MEI HU ${ }^{4}$, NORIO TAKAGI ${ }^{5}$, TOSHIHIKO HIRANO ${ }^{4}$ and HIROO TOYODA ${ }^{1}$ \\ ${ }^{1}$ Department of Clinical Molecular Genetics, School of Pharmacy, Tokyo University of Pharmacy and Life \\ Sciences, Hachioji, Tokyo 192-0392; ${ }^{2}$ Yasuda Women's University, Faculty of Pharmacy, Asaminami-ku, \\ Hiroshima 731-0153; ${ }^{3}$ Department of Cultural History, Seisen University, Shinagawa-ku, Tokyo \\ 141-0022; Departments of ${ }^{4}$ Clinical Pharmacology, ${ }^{5}$ Applied Biochemistry, School of Pharmacy, \\ Tokyo University of Pharmacy and Life Sciences, Hachioji, Tokyo 192-0392, Japan
}

Received July 24, 2013; Accepted September 10, 2013

DOI: 10.3892/ijo.2013.2133

\begin{abstract}
We have demonstrated that an extract from the ripe fruit of Vitex agnus-castus (Vitex) exhibits cytotoxic activities against various types of solid tumor cells, whereas its effects on leukemia cells has not been evaluated to date. In this study, the effects of Vitex and its major component, casticin, on leukemia cell lines, HL-60 and U-937, were investigated by focusing on proliferation, induction of apoptosis and differentiation. Identification and quantitation by NMR spectroscopy showed that casticin accounted for approximate $1 \%$ weight of Vitex. Dose-dependent cytotoxicity of Vitex and casticin was observed in both cell lines, and HL-60 cells were more sensitive to the cytotoxicity of Vitex/casticin compared to U-937 cells. Furthermore, compared to unstimulated HL-60 cells, phorbol 12-myristate 13-acetate (PMA)- and 1,25-dihydroxyvitamin $\mathrm{D}_{3}\left(\mathrm{VD}_{3}\right)$-differentiated HL-60 cells acquired resistance to Vitex/casticin based on the results from cell viability and apoptosis induction analysis. Since the HL-60 cell line is more immature than the U-937 cell line, these results suggested that the levels of cytotoxicity of Vitex/ casticin were largely attributed to the degree of differentiation of leukemia cells; that is, cell lines with less differentiated phenotype were more susceptible than the differentiated ones. RT-PCR analysis demonstrated that PMA upregulated the
\end{abstract}

Correspondence to: Dr Bo Yuan or Dr Hiroo Toyoda, Department of Clinical Molecular Genetics, School of Pharmacy, Tokyo University of Pharmacy and Life Sciences, 1432-1 Horinouchi, Hachioji, Tokyo 192-0392, Japan

E-mail: yuanbo@toyaku.ac.jp

E-mail: toyoda-h@toyaku.ac.jp

Key words: Vitex agnus-castus, casticin, leukemic cells, differentiation, apoptosis induction, intercellular adhesion molecule-1 expression of intercellular adhesion molecule-1 (ICAM-1) in HL-60 cells, and that anti-ICAM-1 monoclonal antibody not only abrogated PMA-induced aggregation and adhesion of the cells but also restored its sensitivity to Vitex. These results suggested that ICAM-1 plays a crucial role in the acquired resistance in PMA-differentiated HL-60 cells by contributing to cell adhesion. These findings provide fundamental insights into the clinical application of Vitex/casticin for hematopoietic malignancy.

\section{Introduction}

Although continuous efforts to exploit efficient therapeutic approaches including molecular target-based drugs for hematopoietic malignancies are ongoing, there is still a growing concern about treatment resistance, disease relapse and side effects of drugs clinically used. Of note, numerous components of edible plants, collectively termed phytochemicals that have beneficial effects for health, are being reported increasingly in the scientific literature and these compounds are now widely recognized as potential therapeutic compounds $(1,2)$.

Vitex agnus-castus is a shrub of the Lamiaceae family (previously known as Verbenaceae family) and found naturally in the Middle East and Southern Europe and China. Ripe fruit of V.agnus-castus has been used to treat patients with various obstetric and gynecological disorders in Europe as well as in China $(3,4)$. Furthermore, we have previously demonstrated that an extract from dried ripe V.agnus-castus (Vitex) exhibits cytotoxic activities against various types of solid tumor cells, such as KATO-III, COLO 201 and MCF-7 $(5,6)$. We further demonstrated that the levels of cytotoxic activity of Vitex were attributed to growth rate of respective cell line, in which cell lines with faster growth rate were more susceptible to Vitex cytotoxicity (5). Casticin has been demonstrated to be one of major components of Vitex (7). Shen et al recently reported that casticin exhibited proliferation inhibitory effect on leukemia cells including K562, Kasumi-1 and 
HL-60, consequently induced cell death through apoptosis and mitotic catastrophe (8). However, to date, the effects of Vitex on hematopoietic cell line has not been evaluated.

Leukemia is a group of malignant diseases with poor prognosis. Recent studies have demonstrated that less differentiated cancer cells, referred to as leukemia stem cells (LSCs), acquired limitless self-renewal through oncogenic transformation, and the incomplete eradication of primary LSCs is closely linked to chemotherapy resistance, and consequently contribute to eventual disease relapse (9). It is well known that there are obvious differences in the degree of differentiation of hematopoietic cells including normal and malignant cells. These findings thus suggest that it is necessary to clarify responses of hematopoietic cell with different degree of differentiation to Vitex and casticin in order to provide fundamental insight into future clinical application of them for leukemia. Since human promyelocytic leukemia HL-60 cell line can be induced to differentiate along either granulocytic or monocytic pathway when treated with respective inducers, it has been shown to be a good model for leukemogenesis research and differentiation study in vitro (10-12).

In the current study, we investigated first the effects of Vitex and casticin on leukemic cell lines HL-60 and U-937, since it is well documented that HL-60 is more immature than U-937 cells although both cells are belong to the monocyte/ macrophage lineage (13). We further evaluated the cytocidal effects of Vitex and casticin against undifferentiated and differentiated HL-60 cells after treatment with phorbol 12-myristate 13-acetate (PMA) and 1,25-dihydroxyvitamin $\mathrm{D}_{3}$ (calcitriol, $\mathrm{VD}_{3}$ ). It is well known that differentiation is accompanied with cell adhesion through adhesion molecules such as integrins, immunoglobulin (Ig)-related molecules, which in turn contribute to acquired resistance to cytocidal reagents $(14,15)$. It has been demonstrated that intercellular adhesion molecule-1 (ICAM-1, also known as CD54), a member of Ig-related molecules, together with leukocyte function-associated antigen-1 (LFA-1), a member of integrins, plays an essential role in cellular adhesion and/or aggregation in PMA-treated HL-60 cells (16). Therefore, contribution of ICAM-1 to the cell adhesion and an alteration of cytocidal effect of Vitex against PMA-treated HL-60 cells was also investigated.

\section{Materials and methods}

General. PMA and calcitriol $\left(\mathrm{VD}_{3}\right)$ were purchased from Wako Pure Chemical Industries (Osaka, Japan) and dissolved in ethanol. Anti-ICAM-1 mouse monoclonal antibody (antiICAM-1 mAb) and casticin were purchased from Calbiochem (La Jolla, CA, USA) and ChromaDex (Irvine, CA, USA), respectively. 2,3-Bis(2-methoxy-4-nitro-5-sulfophenyl)-5[(phenylamino)carbonyl]-2H-tetrazolium hydroxide (XTT) was purchased from Sigma-Aldrich (St. Louis, MO, USA). $\alpha$-Naphthyl Acetate (Non-Specific Esterase) kit was purchased from Muto Pure Chemicals Co. (Tokyo, Japan). Phenazine methosulfate (PMS) and an RNA extraction kit, ISOGEN were obtained from Wako Pure Chemical Industries. Column chromatography was performed on silica gel 60 (Nacalai Tesque, 70-230 mesh) using the indicated solvents. TLC was performed using pre-coated silica gel $60 \mathrm{~F}_{254}$ plates (Merck
$\mathrm{KGaA}$ ) using the indicated solvents. Melting point (mp) was determined with an AS ONE melting point apparatus ATM-02 without correction. ${ }^{1} \mathrm{H}$ NMR spectra were recorded on a Bruker Avance $^{\mathrm{TM}}$ III $600(600 \mathrm{MHz})$ with tetramethylsilane (0 ppm) as an internal standard. ${ }^{13} \mathrm{C}$ NMR spectra were recorded on a Bruker Avance III 600 (150 MHz) with dimethylsulfoxide (DMSO) (39.7 ppm) as an internal standard.

Preparation of an ethanol extract from dried ripened Vitex agnus-castus fruits (Vitex). Preparation of Vitex was carried out according to the methods previously described (6). Briefly, dried ripened $V$. agnus-castus fruit from Israel was gently triturated. The extract was prepared from $1 \mathrm{~g}$ of the triturate with $10 \mathrm{ml}$ of ethanol under reflux for $2 \mathrm{~h}$. The extract was then cooled, filtered, evaporated and dried in a vacuum desiccator, a product of which was designated as Vitex. The yield of Vitex was $0.08-0.1 \mathrm{~g}$ from $1 \mathrm{~g}$ of dried fruit.

Isolation and identification of casticin in Vitex. Vitex (1 g) was subjected to flash column chromatography using silica gel 60 (51.6 g) eluted with chloroform-methanol (250:1). The obtained eleven fractions (F1-F11: $25 \mathrm{ml}$ per one fraction) were analyzed by thin-layer chromatography (TLC) [eluents: chloroform-methanol (20:1)] using commercial casticin as a standard sample. Based on the analysis, five fractions (F5-F9) containing casticin were concentrated under reduced pressure to give a brown oil residue. Then, the residue was further purified by recrystallization from n-hexane-EtOAc $(3: 1)$ to afford casticin as pale yellow crystals. mp $185-188^{\circ} \mathrm{C}$ (n-hexaneEtOAc); ${ }^{1} \mathrm{H}$ NMR (600 MHz, $\left.\mathrm{CDCl}_{3}\right) 3.88(3 \mathrm{H}, \mathrm{s}), 3.92(3 \mathrm{H}$, s), $3.96(3 \mathrm{H}, \mathrm{s}), 3.99(3 \mathrm{H}, \mathrm{s}), 5.71(1 \mathrm{H}, \mathrm{s}), 6.51(1 \mathrm{H}, \mathrm{s}), 6.97$ $(1 \mathrm{H}, \mathrm{d}, \mathrm{J}=8.4 \mathrm{~Hz}), 7.69(1 \mathrm{H}, \mathrm{d}, \mathrm{J}=1.2 \mathrm{~Hz}), 7.73(1 \mathrm{H}, \mathrm{dd}, \mathrm{J}=8.4$, $1.2 \mathrm{~Hz}), 12.60(1 \mathrm{H}, \mathrm{s}) ;{ }^{13} \mathrm{C}$ NMR (150 MHz, DMSO-d6) $\delta 55.9$, 56.7, 59.9, 60.2, 91.5, 105.8, 112.1, 115.3, 120.6, 122.4, 131.8, 138.2, 146.6, 150.5, 151.8, 152.0, 155.8, 158.9, 178.5. Melting point, ${ }^{1} \mathrm{H}$ and ${ }^{13} \mathrm{C}$ NMR spectroscopic data of the crystal were comparable with the reported value of casticin (17).

Cell cultures and Vitex/casticin treatment. Leukemic cell lines HL-60 and U-937 were purchased from the Health Science Research Resources Bank (Tokyo, Japan). Peripheral blood mononuclear cells (PBMNC) were isolated from three healthy volunteers (Vitex treatment; $26 \pm 1$, and casticin treatment; $26.3 \pm 3.21$ years of age), as previously described (18). Briefly, $10 \mathrm{ml}$ of heparinized blood was loaded on $3.5 \mathrm{ml}$ of Ficoll Hypaque (Nakalai Tesque, Kyoto, Japan) and centrifuged at 2,000 rpm for $20 \mathrm{~min}$, and PBMNC were separated. Both the cell lines and PBMNC were cultured in RPMI-1640 medium (Gibco, Grand Island, NY, USA) supplemented with $10 \%$ heat-inactivated fetal bovine serum (Invitrogen, Carlsbad, CA, USA) and antibiotics [100 U/ml penicillin and $100 \mu \mathrm{g} / \mathrm{ml} \mathrm{strep-}$ tomycin (Invitrogen)] at $37^{\circ} \mathrm{C}$ in a humidified atmosphere $(5 \%$ $\mathrm{CO}_{2}$ in air). Vitex and casticin were dissolved in DMSO. As for unstimulated HL-60 and U-937 control cells, and PBMNC, 2X $10^{5}$ cells/ml were precultured for $12 \mathrm{~h}$, followed by the treatment with Vitex or casticin at various concentrations indicated at $37^{\circ} \mathrm{C}$ for a designated time. Control samples were prepared by treating cells with culture medium containing vehicle reagent, DMSO alone (final concentration: $0.1 \%$ ). This study was approved by the IRB committee of Tokyo University 
Table I. PCR primers and conditions used in the present study.

A, PCR primers and optimal numbers of PCR cycle

\begin{tabular}{ll}
\hline Target mRNA & \multicolumn{1}{c}{ DNA sequence of PCR primer } \\
\hline CD11b & Sense: 5'-CCCCCAGGTCACCTTCTCCG-3' \\
& Antisense: 5'-GCTCTGTCGGGAAGGAGCCG-3' cycles \\
ICAM-1 & Sense: 5'-GCAATGTGCAAGAAGATAGCCAACC-3' \\
& Antisense: 5'-ACACTTCACTGTCACCTCGGTCCCT-3' \\
$\beta$-actin & Sense: 5'-CCTTCCTGGGCATGGAGTCCTG-3' \\
& Antisense: 5'-GGAGCAATGATCTTGATCTTC-3' \\
\hline
\end{tabular}

B, Conditions for PCR

\begin{tabular}{lccccccc}
\hline & \multicolumn{2}{c}{ Denaturation reaction } & & \multicolumn{2}{c}{ Annealing reaction } & & \multicolumn{2}{c}{ Extension reaction } \\
\cline { 2 - 7 } \cline { 5 - 7 } Target mRNA & $\begin{array}{c}\text { Temp. } \\
\left({ }^{\circ} \mathrm{C}\right)\end{array}$ & $\begin{array}{c}\text { Time } \\
(\mathrm{sec})\end{array}$ & \multirow{2}{*}{$\begin{array}{c}\text { Temp. } \\
\left({ }^{\circ} \mathrm{C}\right)\end{array}$} & $\begin{array}{c}\text { Time } \\
(\mathrm{sec})\end{array}$ & $\begin{array}{c}\text { Temp. } \\
\left({ }^{\circ} \mathrm{C}\right)\end{array}$ & $\begin{array}{r}\text { Time } \\
(\mathrm{sec})\end{array}$ \\
\hline CD11b & 94 & 60 & 62 & 60 & 72 & 600 \\
ICAM-1 & 94 & 60 & 60 & 120 & 72 & 180 \\
$\beta$-actin & 94 & 45 & 60 & 45 & 72 & 120 \\
\hline
\end{tabular}

of Pharmacy and Life Sciences. An informed consent was obtained from all healthy volunteers.

Induction of differentiation and Vitex/casticin treatment. To induce differentiation, cells $\left(3 \times 10^{5}\right.$ cells $\left./ \mathrm{ml}\right)$ were exposed to $10 \mathrm{ng} / \mathrm{ml}$ PMA for $48 \mathrm{~h}$, or $100 \mathrm{nM} \mathrm{VD}_{3}$ for $96 \mathrm{~h}$ with medium change at 48-h post-exposure, respectively. As for control groups, cells were exposed to vehicle reagent, ethanol alone, at a final concentration of $0.1 \%$. Morphological changes of HL-60 cells were observed using phase-contrast microscope (CK2, Olympus, Japan). After exposure to PMA, non-adherent cells were discarded, and tightly adherent cells were designated as PMA-treated HL-60 cells and harvested for cell counting. The number of PMA-treated HL-60 cells was $\sim 3 \times 10^{6}$ in $5 \mathrm{ml}$ medium (i.e. at the density of $6 \times 10^{5}$ cells $/ \mathrm{ml}$ ) each time. Moreover, after exposure to $\mathrm{VD}_{3}$, loosely adherent cells were designated as $\mathrm{VD}_{3}$-treated HL-60 cells. After the cell density of $\mathrm{VD}_{3}$-treated HL-60 and control group cells were also adjusted to $6 \times 10^{5}$ cells $/ \mathrm{ml}$ in fresh medium, the three kinds of cells were treated with Vitex or casticin at various concentrations indicated at $37^{\circ} \mathrm{C}$ for a designated time. Furthermore, in order to elucidate the involvement of ICAM-1 in the cytotoxicity of Vitex against differentiated HL-60 cells, HL-60 cells were treated with $10 \mathrm{ng} / \mathrm{ml}$ of PMA in the presence or absence of $1 \mu \mathrm{g} / \mathrm{ml}$ of anti-ICAM- $1 \mathrm{mAb}$ for $48 \mathrm{~h}$, followed by the treatment with $50 \mu \mathrm{g} / \mathrm{ml}$ Vitex for $24 \mathrm{~h}$.

Cell viability assay. Cell viability was determined by XTT dye-reduction assay according to the method previously described (19). Briefly, after treatment with various concentrations of Vitex or casticin for a designated time, cells were washed with PBS twice and resuspended in appropriate volume of PBS. An aliquot $(0.2 \mathrm{ml})$ of cell suspension was inoculated into 96 -well micro-plates followed by the addition of $50 \mu 1$
XTT/PMS mixed solution [1.5 mM XTT and $0.025 \mathrm{mM}$ PMS]. After incubation at $37^{\circ} \mathrm{C}$ for $4 \mathrm{~h}$, plates were mixed on a mechanical plate shaker, and absorbance at $450 \mathrm{~nm}$ was measured with a microplate reader (Safire, Tecan, Switzerland). The relative cell viability was expressed as the ratio of the absorbance of each treatment group against those of the corresponding untreated control group. The $\mathrm{IC}_{50}$ value of Vitex and casticin was calculated from the cell proliferation inhibition curve after $24 \mathrm{~h}$ of treatment.

Nonspecific esterase activity. To identify nonspecific esterase (NSE) activity, a commercially available kit for NSE staining was used. Briefly, smear preparations of stimulated cells were fixed with formalin-acetone fixative solution for $30 \mathrm{sec}$ at $4^{\circ} \mathrm{C}$, then washed with running water, followed by incubation with reaction agent [10 mg of fast garnet GBC salt, $10 \mu 1$ of naphthyl butyrate, $0.5 \mathrm{ml}$ of ethylene glycol monomethyl ether (EGME) and $9.5 \mathrm{ml}$ of phosphate buffer (1/15 M, pH 6.3)] for $30 \mathrm{~min}$ at $37^{\circ} \mathrm{C}$. After washing with running water, these preparations were stained with Karachi's hematoxylin for $10 \mathrm{~min}$ at $37^{\circ} \mathrm{C}$, then washed with running water for achieving proper color intensity. After drying, smear preparations were enclosed with glycerol-gelatin, followed by observation with inverted microscope (Axiovert 200, Carl Zeiss, Germany) and photographed with the software of AxioVision 4.5 (Carl Zeiss). Furthermore, to conduct the sodium fluoride $(\mathrm{NaF})$ inhibition test, the above-mentioned reaction agent was replaced with reaction agent containing $4.5 \mathrm{mg}$ of $\mathrm{NaF}$.

\section{Determination of apoptosis}

DNA gel electrophoresis. DNA preparation and agarose gel electrophoresis were carried out according to a method previously reported (19). Extracted DNA was dissolved in TE buffer (10 mM Tris-HCl, pH 8.0, 1 mM EDTA). DNA 


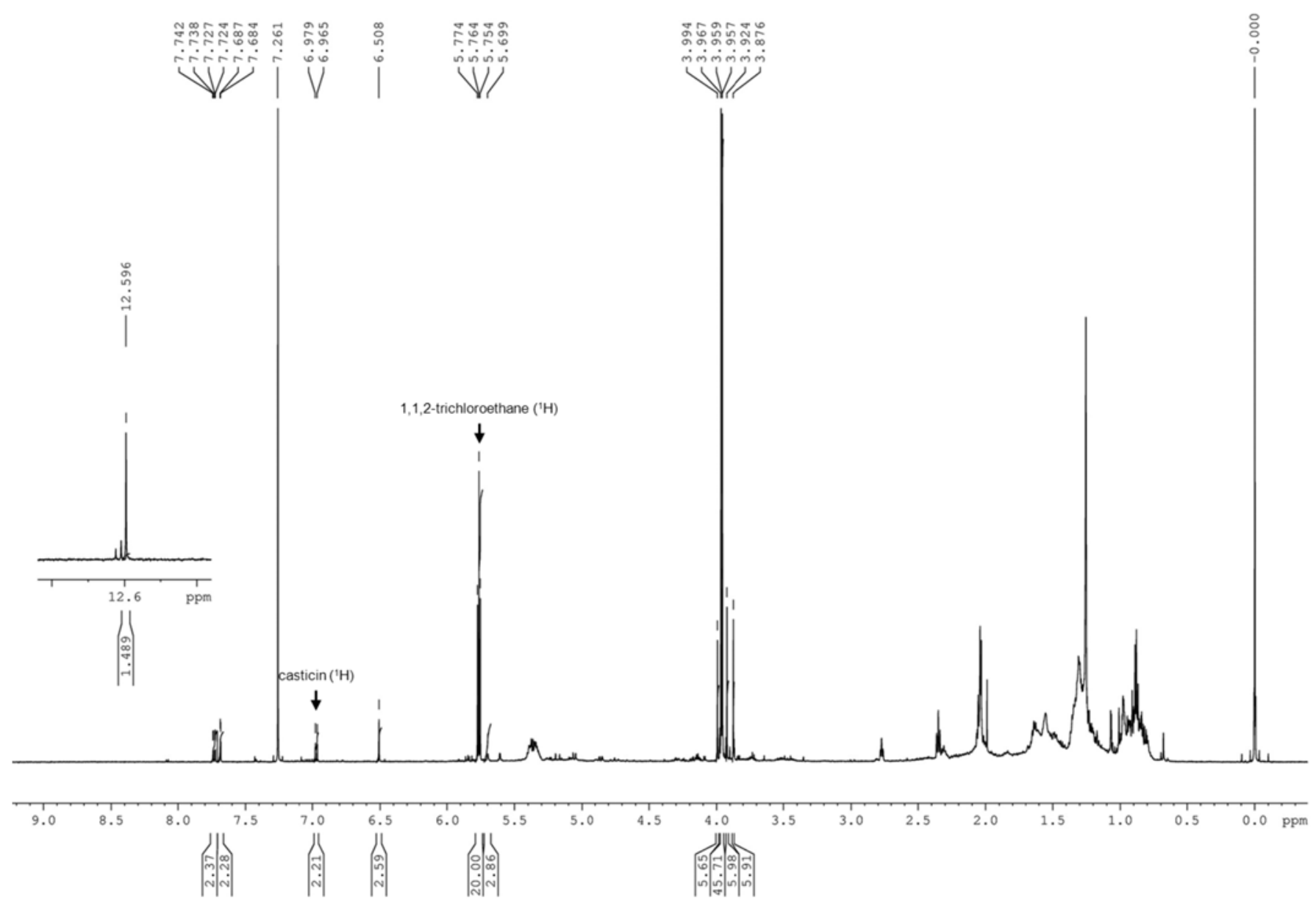

Figure 1. 1H NMR spectrum of fractions F5-F9 $(100.3 \mathrm{mg})\left(600 \mathrm{MHz}, \mathrm{CDCl}_{3}\right)$. Isolation and identification were conducted as described in Material and methods. F5 and F9 fractions containing casticin obtained by chromatographic separation from Vitex $(1 \mathrm{~g})$ were concentrated under reduced pressure to give a brown oil residue $(100.3 \mathrm{mg}) .{ }^{1} \mathrm{H}$ NMR analysis of the residue was performed using 1,1,2-trichloroethane $(0.25 \mathrm{mmol}, 46 \mu \mathrm{l})$ as an internal standard.

samples $(\sim 20 \mu \mathrm{g} / 20 \mu \mathrm{l})$ and a Tracklt ${ }^{\mathrm{TM}} 100 \mathrm{bp}$ DNA Ladder (Invitrogen) as a DNA size marker were electrophoresed on a $2 \%$ agarose gel (Agarose X, Nippon Gene, Tokyo, Japan) using TBE buffer ( $89 \mathrm{mM}$ Tris, $89 \mathrm{mM}$ boric acid, 2 mM EDTA). Gels were stained with ethidium bromide and viewed under printgraph (ATTO Corp., Tokyo, Japan).

Hoechst 33342 staining. After treatment with 30 and $70 \mu \mathrm{g} / \mathrm{ml}$ Vitex, respectively, for $24 \mathrm{~h}$, cells were washed twice with PBS and fixed with $1 \%$ glutaraldehyde/PBS at $4^{\circ} \mathrm{C}$ for at least $2 \mathrm{~h}$. Then, cell were washed twice with PBS and resuspended in $10 \mu \mathrm{l}$ of $200 \mu \mathrm{M}$ Hoechst 33342 (Calbiochem)/PBS for $15 \mathrm{~min}$. The stained cells were enclosed in FluorSave ${ }^{\mathrm{TM}}$ reagent in a mounting medium and then viewed using a fluorescence microscopy, Axiovert 200.

Reverse transcription-polymerase chain reaction (RT-PCR) analysis. Total RNA isolation and complementary DNA were prepared according to methods previously described with modifications (20). Total RNA was extracted from cells using an RNA extraction kit, ISOGEN. Complementary DNA was synthesized from $1 \mu \mathrm{g}$ of RNA using $100 \mathrm{pmol}$ random primer and 50 units of moloney murine leukemia virus reverse transcriptase (Invitrogen) in a total volume of $20 \mu \mathrm{l}$, according to the manufacturer's instructions. PCR was performed according to the methods previously described (20) using a Takara Thermal Cycler MP (Takara Shuzo Co., Osaka, Japan). DNA sequence of PCR primers and optimal conditions for PCR are shown in Table I. PCR primers were purchased from Sigma-Aldrich (Hokkaido, Japan). PCR products and a Tracklt $^{\mathrm{TM}} 100$ bp DNA Ladder as a DNA size marker were electrophoresed on a $2 \%$ UltraPure $^{\mathrm{TM}}$ agarose gel (Invitrogen), respectively, and visualized by ethidium bromide staining, followed by viewing under UV Light Printgraph.

Statistical analysis. Experiments were independently repeated three times, and the results are shown as the mean \pm standard deviation (SD) of three assays. Student's t-test was applied, and $\mathrm{p}<0.05$ was considered as significant.

\section{Results}

Identification and quantitation of casticin in Vitex. The above-mentioned F5-F9 fractions containing casticin obtained by chromatographic separation from Vitex ( $1 \mathrm{~g})$ were concentrated under reduced pressure to give a brown oil residue (100.3 mg). ${ }^{1} \mathrm{H}$ NMR analysis of the residue using 1,1,2-trichloroethane $(0.25 \mathrm{mmol}, 46 \mu \mathrm{l})$ as an internal standard indicated that the amount of casticin in the residue was estimated to be $0.0275 \mathrm{mmol}(10.3 \mathrm{mg}$ ) (Fig. 1). The analysis indicated that casticin accounted for approximate $1 \%$ weight of Vitex. 
A

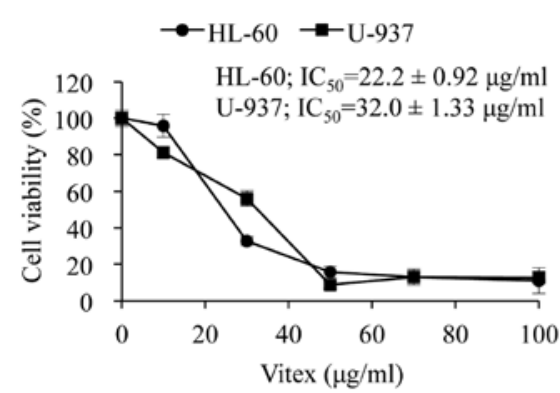

C

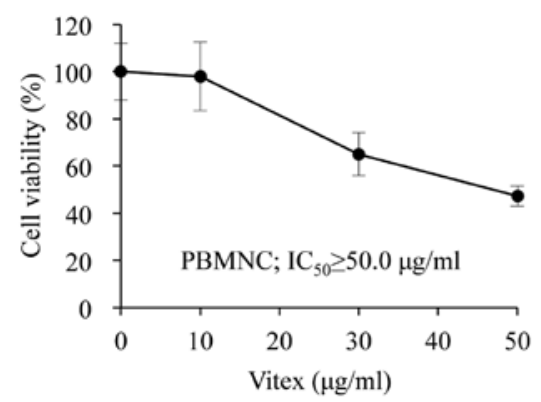

B

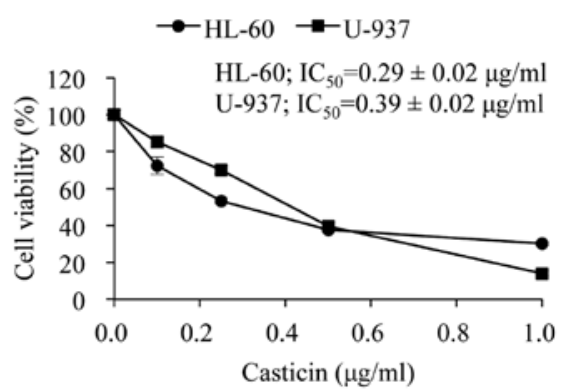

D

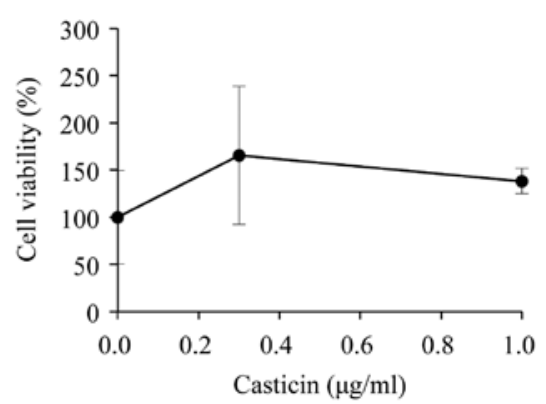

Figure 2. Cytocidal effects of Vitex and casticin on HL-60, U-937 cells. After treatment with various concentrations of Vitex (10,30,50,70 and 100 $\mu \mathrm{g} / \mathrm{ml})$ and casticin $(0.1,0.25,0.5$ and $1.0 \mu \mathrm{g} / \mathrm{ml})$ for $24 \mathrm{~h}$, the cytotoxicity was analyzed by XTT assay in HL-60 and U-937 cells (A and B), as well as PBMNC (C and D), as described in Materials and methods.

Table II. Acquisition of resistance to Vitex and casticin in HL-60, PMA-treated HL-60 and $\mathrm{VD}_{3}$-treated HL-60 cells.

\begin{tabular}{|c|c|c|}
\hline & Vitex & Casticin \\
\hline Cells & $\mathrm{IC}_{50}$ value $(\mu \mathrm{g} / \mathrm{ml})$ & $\mathrm{IC}_{50}$ value $(\mu \mathrm{g} / \mathrm{ml})$ \\
\hline HL-60 & $28.3 \pm 0.17$ & $0.46 \pm 0.01$ \\
\hline PMA-treated HL-60 & $>100^{\mathrm{a}}$ & $>1.0^{\mathrm{a}}$ \\
\hline $\mathrm{VD}_{3}$-treated HL-60 & $39.3 \pm 0.55^{\mathrm{a}}$ & $>1.0^{\mathrm{a}}$ \\
\hline
\end{tabular}

After treatment with various concentrations of Vitex $(10,30,50,70$ and $100 \mu \mathrm{g} / \mathrm{ml})$ and casticin $(0.1,0.25,0.5$ and $1.0 \mu \mathrm{g} / \mathrm{ml})$ for $24 \mathrm{~h}$, the cytotoxicity was investigated by XTT assay in HL-60, PMA- and $\mathrm{VD}_{3}$-treated HL-60 cells, respectively, as described in Materials and methods. Significant differences were observed between undifferentiated HL-60 and differentiated HL-60 cells ( ${ }^{\mathrm{a}} \mathrm{p}<0.01$ vs. HL-60 cells).

Cytocidal effects of Vitex and casticin on HL-60 and U-937 cells. After $24 \mathrm{~h}$ of cultivation, the ratio of the absorbance at $450 \mathrm{~nm}$ of both HL-60 and U-937 cells compared to that at $0 \mathrm{~h}$ increased by $\sim 2.5$-fold, indicating cell growth rate of the two cells was almost same. Although Vitex exhibited cytotoxic activities against both cells in a dose-dependent manner, a significant difference in the $\mathrm{IC}_{50}$ value was observed between HL-60 and U-937 cells $(22.2 \pm 0.92 \mu \mathrm{g} / \mathrm{ml}$ in HL-60; $32.0 \pm 1.33 \mu \mathrm{g} / \mathrm{ml}$ in U-937; p<0.01) (Fig. 2A). Furthermore, similar phenomena were observed in both cells when treated with casticin $(0.29 \pm 0.02 \mu \mathrm{g} / \mathrm{ml}$ in HL-60; $0.39 \pm 0.02 \mu \mathrm{g} / \mathrm{ml}$ in U-937; p<0.01) (Fig. 2B), indicating HL-60 is more sensitive to the cytotoxicity of Vitex and casticin compared to U-937.
Although a relatively high concentration of Vitex exhibited cytocidal effect against PBMNC, the $\mathrm{IC}_{50}$ value was more than $50 \mu \mathrm{g} / \mathrm{ml}$ and was $\sim 2$ times higher than that in both leukemic cell lines (Fig. 2C). Of note, no apparent cytotoxicity of casticin was observed in PBMNC when treated with concentrations showing significant cytotoxicity in both leukemic cell lines (Fig. 2D).

Identification of differentiation induced by $P M A$ and $V D_{3}$ in $H L-60$ cells. After exposure to $10 \mathrm{ng} / \mathrm{ml}$ PMA and $100 \mathrm{nM}$ $\mathrm{VD}_{3}$ for $48 \mathrm{~h}$ and $96 \mathrm{~h}$, respectively, the mature phenotype was confirmed by cell attachment, NSE activity, and manifestation of a maturation surface marker, CD11b. Whereas unstimulated HL-60 cells grew as single cell suspension cultures, PMA-treated HL-60 cells adhered tightly to plastic culture plate and showed apparent cellular aggregation, and morphology became macrophage-like (Fig. 3A). On the other hand, $\mathrm{VD}_{3}$-treated HL-60 cells adhered loosely to plastic culture plate and its morphology became monocytoid (Fig. 3A). The NSE is a well-known selective cytochemical marker for the monocyte/macrophage lineage (21). Consistent with these previous reports, NSE activity (brownish-red granulation) was observed in PMA- and $\mathrm{VD}_{3}$-treated HL-60 cells, but not in untreated HL-60 cells (Fig. 3B). Furthermore, NaF abolished NSE activity as expected (Fig. 3B). A predominant increase in CD11b mRNA was coincidentally observed in both PMA- and $\mathrm{VD}_{3}$-treated HL-60 cells (Fig. 3C).

Acquisition of resistance to Vitex and casticin in PMA- and $V D_{3}$-treated HL-60 cells. Compared to unstimulated control HL-60 cells, PMA- and VD -treated HL-60 cells exhibited acquired resistance to both Vitex and casticin treatment (Table II), although the $\mathrm{IC}_{50}$ value of unstimulated control 

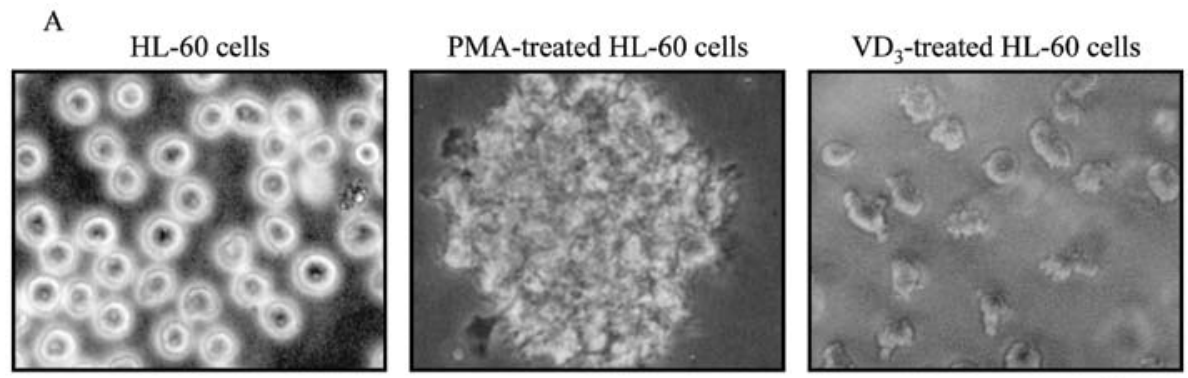

$20 \mu \mathrm{m}$
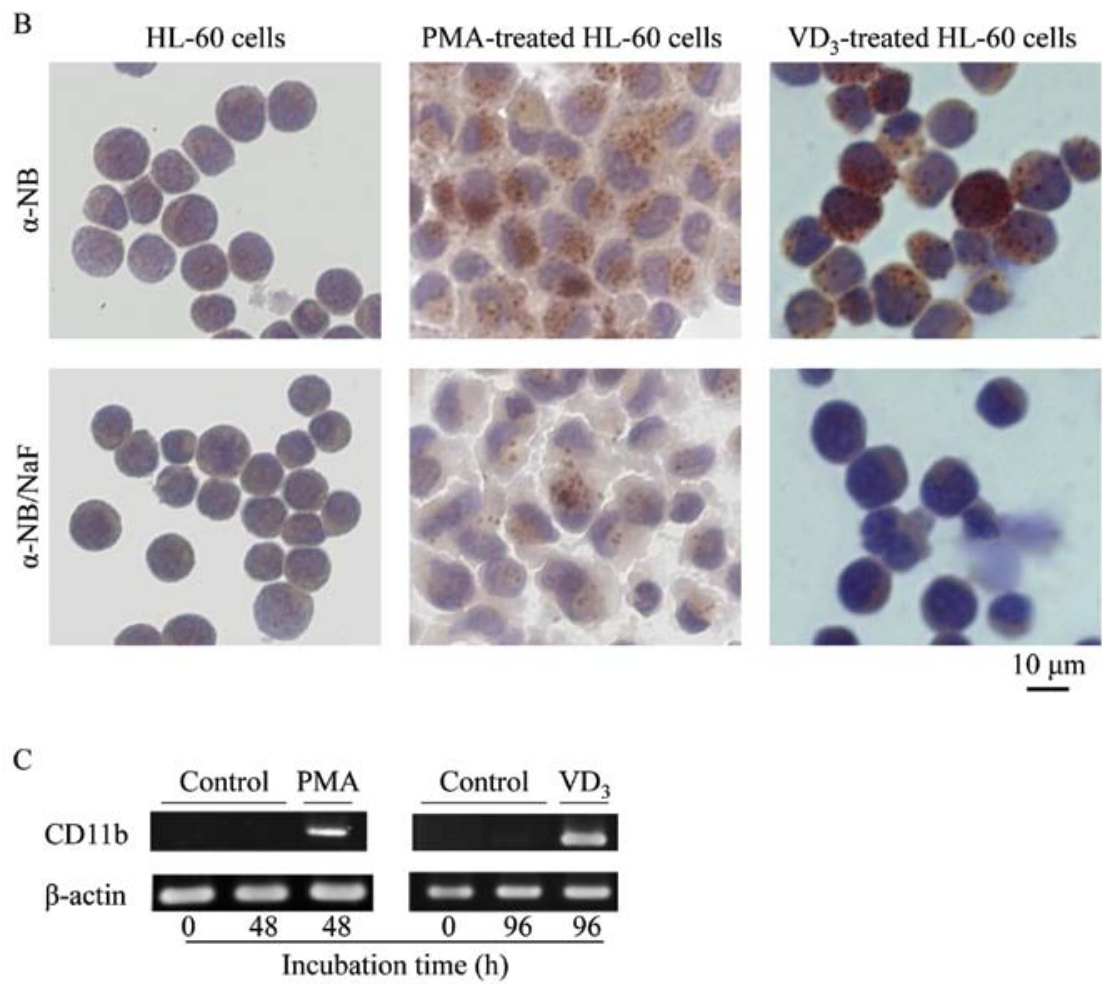

Figure 3. Identification of differentiation induced by PMA or VD 3 in HL-60 cells. After treatment with $10 \mathrm{ng} / \mathrm{ml}$ PMA for $48 \mathrm{~h}$, and $100 \mathrm{~nm}$ VD 3 for $96 \mathrm{~h}$ with medium change at 48-h post-exposure, respectively, morphology analysis (A), NSE activity (B) and CD11b expression (C) were evaluated as described in Materials and methods. A representative electrophoretic profile is shown from three independent experiments.

HL-60 cells indicated in Table II was different from that in Fig. 2 due to different cell-density at the point of treatment. In the case of Vitex treatment, the $\mathrm{IC}_{50}$ value was $>100 \mu \mathrm{g} / \mathrm{ml}$ and $39.3 \pm 0.55 \mu \mathrm{g} / \mathrm{ml}$ in PMA- and $\mathrm{VD}_{3}$-treated HL-60 cells, respectively, and significantly higher than that in unstimulated control HL-60 cells $(28.3 \pm 0.17 \mu \mathrm{g} / \mathrm{ml} ; \mathrm{p}<0.05)$. As for casticin treatment, the $\mathrm{IC}_{50}$ value increased more than two times in both PMA- and $\mathrm{VD}_{3}$-treated HL-60 cells compared to that in unstimulated control cells. Furthermore, an evident distinct increase of DNA fragmentation ladder representing apoptosis induction was observed at concentrations starting from $30 \mu \mathrm{g} / \mathrm{ml}$ Vitex in unstimulated control HL-60 cells (Fig. 4A). However, the DNA fragmentation was clearly abrogated in both differentiated HL-60 cells (Fig. 4A). Hoechst 33342 fluorescent staining also demonstrated that DNA fragmentation was significantly abrogated in PMA-stimulated cells even when treated with as high as $70 \mu \mathrm{g} / \mathrm{ml}$ Vitex (Fig. 4B). On the other hand, we also observed that a certain degree of apoptotic population was observed in the flasks that were not treated with Vitex after 24 additional hours of culture
(Fig. 4B), similar to a previous study showing that a population of PMA-treated HL-60 cells spontaneously detached and became dead cells $(14,22)$.

Contribution of ICAM-1 to acquired resistance against Vitex cytotoxicity in PMA-treated HL-60 cells. As shown in Fig. 5A, PMA induced cellular aggregation and adhesion within $48 \mathrm{~h}$ after stimulation. However, the addition of $1 \mu \mathrm{g} / \mathrm{ml}$ antiICAM-1 mAb significantly abrogated the effects of PMA. In agreement with results presented in Table II, no cytotoxicity was observed in PMA-treated HL-60 when treated with $50 \mu \mathrm{g} / \mathrm{ml}$ Vitex exhibiting apparent cytocidal effect against unstimulated control HL-60 cells (Fig. 5B and C). Again, the addition of anti-ICAM-1 mAb abrogated the acquired resistance to Vitex (Fig. 5C).

Alterations of ICAM-1 gene expression in PMA-treated HL-60 cells treated with Vitex. The expression of ICAM-1 mRNA was observed in PMA-treated HL-60 cells, but not in unstimulated control cells (Fig. 6), indicating treatment with PMA induced 

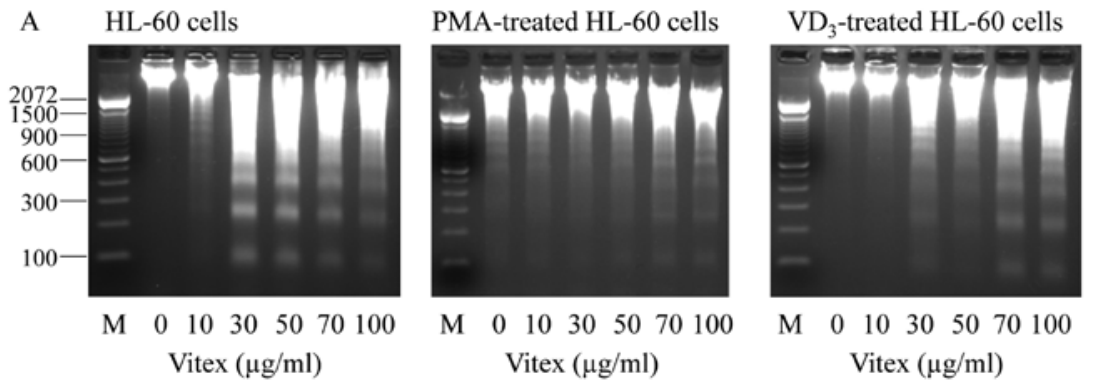

B

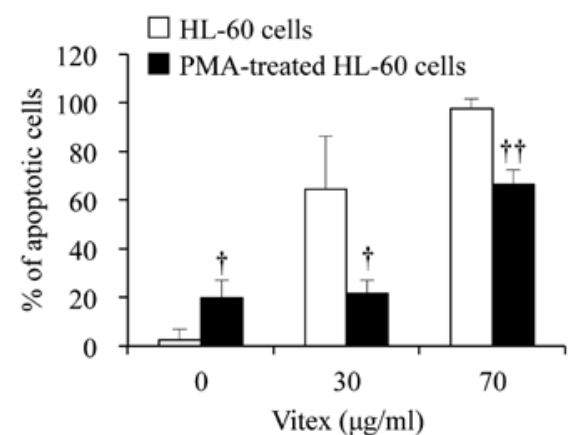

Figure 4. Acquired resistance to Vitex-induced apoptosis in PMA- and VD-treated HL-60 cells. (A) DNA electrophoresis pattern of HL-60, PMA- and $\mathrm{VD}_{3}$-treated HL-60 cells treated with various concentrations of Vitex for $24 \mathrm{~h}$. A representative electrophoretic profile is shown from three independent experiments. (B) The ratio of the number of apoptotic cells against the total number of cells. After treatment with 30 and $70 \mu \mathrm{g} / \mathrm{ml}$ Vitex, respectively, for $24 \mathrm{~h}$, cells were stained using Hoechst 33342, as described in Materials and methods. Apoptotic cells with condensation and/or fragmentation of nuclei and total cells were counted and averaged from three different viewings, respectively. Data are shown as the means and SD from three independent experiments. Significant differences were observed between HL-60 and PMA-treated HL-60 cells $\left({ }^{\dagger} \mathrm{p}<0.05 ;{ }^{\dagger \dagger} \mathrm{p}<0.01\right)$.

A

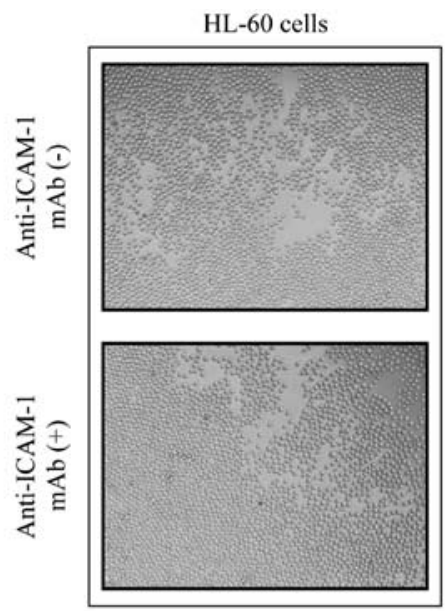

B

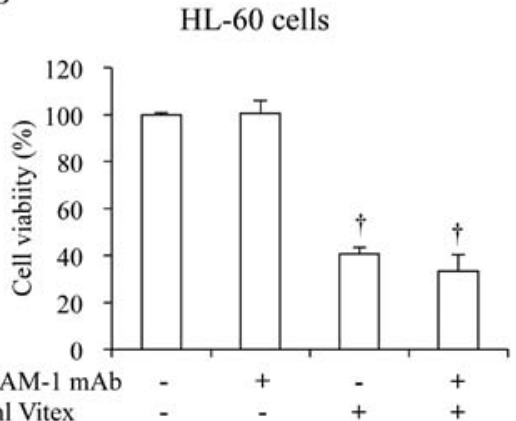

PMA-treated HL-60 cells

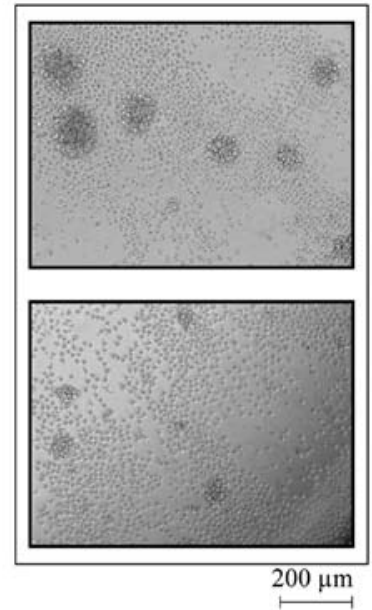

C

PMA-treated HL-60 cells

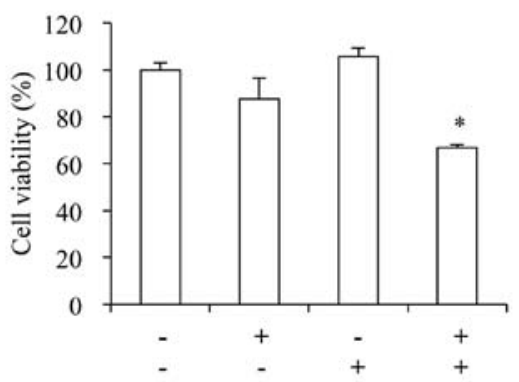

Figure 5. Contribution of ICAM-1 to acquired resistance against Vitex cytotoxicity in PMA-treated HL-60 cells. Morphological changes of HL-60 cells treated with PMA in the presence or absence of anti-ICAM-1 mAb for $48 \mathrm{~h}$ were observed using an inverted microscope (A). After treatment with $50 \mu \mathrm{g} / \mathrm{ml} \mathrm{Vitex}$ in the presence or absence of anti-ICAM-1 mAb for $24 \mathrm{~h}$, cytotoxicity was investigated by XTT assay in HL-60 and PMA-treated HL-60 cells (B and C) as described in Materials and methods. Significant differences were observed between treated groups and control groups [ ${ }^{\dagger} \mathrm{p}<0.01$, vs. control (HL-60 cells); ${ }^{*} \mathrm{p}<0.05$, vs. control (PMA-treated HL-60 cells)]. 


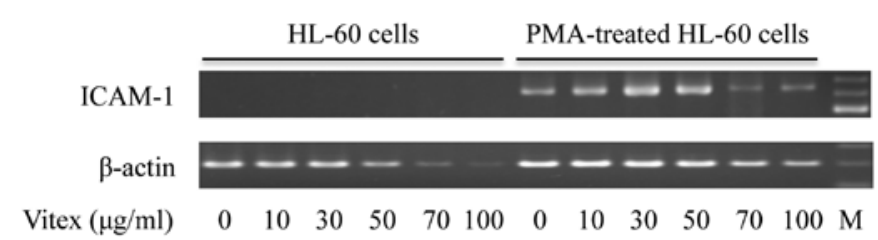

Figure 6. Alterations of ICAM-1 gene expression in PMA-treated HL-60 cells treated with Vitex. After treatment with various concentrations of Vitex for $24 \mathrm{~h}$, the expression profile of ICAM-1 mRNA was assessed by RT-PCR, followed by an agarose gel electrophoresis as described in Materials and methods. Sizes of DNA markers in lane M are shown as base pairs.

ICAM-1 gene expression associated with cellular adhesion and aggregation. Consistent with apparent cytotoxicity induced by Vitex in unstimulated control cells, the expression level of $\beta$-actin was clearly downregulated when treated with $>50 \mu \mathrm{g} /$ ml Vitex. However, only a slight downregulation of $\beta$-actin expression level was observed in PMA-treated HL-60 cells even when treated with as high as 70 and $100 \mu \mathrm{g} / \mathrm{ml}$ Vitex. Noteworthy, a clear upregulation of ICAM-1 mRNA was observed in PMA-treated HL-60 cells treated with Vitex ranging from 10 to $50 \mu \mathrm{g} / \mathrm{ml}$, which exhibited no cytocidal effect against the cells. Furthermore, a prominent decrease in the expression level of ICAM-1 mRNA was observed in PMA-treated HL-60 when treated with $>70 \mu \mathrm{g} / \mathrm{ml}$ Vitex.

\section{Discussion}

In the current study, we demonstrated that HL-60 is more sensitive to the cytotoxicity of Vitex/casticin compared to U-937, although growth rates of two cell lines were almost the same. Based on the fact that HL-60 is more immature than U-937 (13), we hypothesized that unlike solid tumor cells, the levels of cytotoxic activity of Vitex/casticin were largely attributed to degree of differentiation of leukemic cells. Furthermore, similar to our previous studies showing no apparent cytotoxicity against non-tumor cells, such as human uterine cervical canal fibroblasts and embryo fibroblasts (5), much less cytotoxicity was observed in PBMNC when treated with concentrations of Vitex/casticin showing significant cytotoxicity in both leukemic cell lines. These results suggest that Vitex/casticin possess a selective cytotoxic activity against tumor cells.

In order to verify our hypothesis, the cytocidal effects of Vitex/casticin were investigated in both undifferentiated and differentiated HL-60 cells. Morphology analysis, NSE activity and CD11b expression profiles demonstrated that HL-60 cells successfully differentiated into monocyte/macrophage lineage after stimulation by PMA and $\mathrm{VD}_{3}$, respectively, as demonstrated in previous studies $(12,23)$. As expected, differentiated HL-60 cells by both PMA and $\mathrm{VD}_{3}$ exhibited acquired resistance to both Vitex and casticin compared to unstimulated control HL-60. We demonstrated that a contribution of apoptosis induction was linked to Vitex-induced cytocidal effects in KATO-III and COLO $201(6,19,24)$. The current study demonstrated that not only solid tumor cells, but also leukemic cell line HL-60 underwent apoptosis after treatment with Vitex. Again, apoptosis induction was clearly abrogated in PMA/VD3-stimulated HL-60 cells when treated with Vitex, even if at the concentrations as high as $70 \mu \mathrm{g} / \mathrm{ml}$. These results thus strongly support our hypothesis that the degree of differentiation contributed to the sensitivity of leukemic cells to cytotoxic activity of Vitex.

Cell adhesion molecules, such as integrins, Ig-related molecules, and selectins, are well known to be involved in cell-cell/cell-substrate adhesion, which plays a major role in regulating various cellular processes including the maintenance of cell survival $(15,25)$. ICAM-1 is one of Ig-related molecules and recognized by integrins such as LFA-1, consequently contributing to cell adherence (25). Previous studies have demonstrated that ICAM-1 together with LFA-1 plays an essential role in cellular adhesion and/or aggregation in HL-60 cells induced by PMA or TNF- $\alpha(16,26)$. Furthermore, Solary et al have previously demonstrated a strong inhibition of apoptosis induced by camptothecin, and vinblastine in PMA-differentiated HL-60 cells (14). They further suggested that inactivation of a cytoplasmic activity (e.g. inhibition of endonuclease or its activation pathway) resulted from PMA-induced differentiation contributed to the inhibitory effects, whereas the correlation of the cell adhesion molecules was not clarified (14).

In the current study, we demonstrated that anti-ICAM-1 $\mathrm{mAb}$ not only abrogated PMA-induced aggregation and adhesion of HL-60 cells, but also restored its sensitivity to Vitex. We also demonstrated that a clear upregulation of ICAM-1 mRNA was observed in PMA-treated HL-60 cells when treated with less than $50 \mu \mathrm{g} / \mathrm{ml}$ Vitex. Although it was not clarified whether ICAM-1 contributed to cell-cell or cell-substrate adhesion, respectively, or both, in our experimental system, and the detailed experimental studies for the upregulation of ICAM-1 mRNA in PMA-treated HL-60 are needed, there is little doubt that ICAM-1 plays a crucial role in the acquisition of resistance to Vitex. It is well established that anti-apoptotic pathways initiated by cell adhesion are operative in both solid and hematopoietic tumor cells and, further cause resistance to various cytotoxic drugs with different mechanisms $(27,28)$. Therefore, it is suggested that therapeutical efficacy could be achieved by the reversal of drug resistance resulted from cell adhesion.

In conclusion, we demonstrated for the first time that the levels of cytotoxicity of Vitex/casticin were largely attributed to degree of differentiation of hematopoietic cell lines, in which cell lines with less differentiated phenotype were more susceptible than the differentiated ones. These results suggest a potential future application of Vitex/casticin in combination with clinically used anticancer drugs in view of developing more efficient strategy to eradicate primary LSCs, which contribute to eventual disease relapse. We revealed that administration of Vitex significantly suppressed tumor growth in COLO 201 xenograft mice (24). Furthermore, we recently reported that 5-FU in combination with Vitex achieved an enhanced cytocidal effect on COLO 201 cells (29). We also clarified that ICAM-1 resulted from PMA-induced differentiation plays a crucial role in the acquisition of resistance to Vitex in PMA-treated HL-60 cells, supporting the opinion that therapeutically beneficial outcomes can be achieved through reversal of the cell adhesion. It is interesting to note that Vitexins, which is isolated from the seed of Chinese herb Vitex Negundo and bears a basic flavonoid structure, shows cytotoxic and antitumor effects against breast, prostate and ovarian cancer cells through 
apoptosis induction via an intrinsic pathway based on in vitro and in vivo xenograft tumor models (30). Therefore, our results provide new insight into the clinical use of Vitex for not only solid tumors but also hematopoietic malignancy.

\section{Acknowledgements}

This work was supported in part by grants from Japan China Medical Association to Bo Yuan. This work was also supported in part by grants from the Ministry of Education, Culture, Sports, Science and Technology and by the Promotion and Mutual Aid Corporation for Private Schools of Japan.

\section{References}

1. Fimognari C, Lenzi M and Hrelia P: Chemoprevention of cancer by isothiocyanates and anthocyanins: mechanisms of action and structure-activity relationship. Curr Med Chem 15: 440-447, 2008.

2. Yuan B, Imai M, Kikuchi H, Fukushima S, Hazama S, Akaike T, Yoshino Y, Ohyama K, Hu X, Pei X and Toyoda H: Cytocidal effects of polyphenolic compounds, alone or in combination with, anticancer drugs against cancer cells: potential future application of the combinatory therapy. In: Apoptosis and Medicine. Ntuli TM (ed). InTech, Croatia, pp155-174, 2012.

3. Schellenberg R: Treatment for the premenstrual syndrome with agnus castus fruit extract: prospective, randomised, placebo controlled study. BMJ 322: 134-137, 2001.

4. Ma L, Lin S, Chen R, et al: Treatment of moderate to severe premenstrual syndrome with Vitex agnus castus (BNO 1095) in Chinese women. Gynecol Endocrinol 26: 612-616, 2010.

5. Ohyama K, Akaike T, Hirobe C, et al: Cytotoxicity and apoptotic inducibility of Vitex agnus-castus fruit extract in cultured human normal and cancer cells and effect on growth. Biol Pharm Bull 26: $10-18,2003$.

6. Ohyama K, Akaike T, Imai M, et al: Human gastric signet ring carcinoma (KATO-III) cell apoptosis induced by Vitex agnuscastus fruit extract through intracellular oxidative stress. Int J Biochem Cell Biol 37: 1496-1510, 2005.

7. Chen SN, Friesen JB, Webster D, et al: Phytoconstituents from Vitex agnus-castus fruits. Fitoterapia 82: 528-533, 2011

8. Shen JK, Du HP, Yang M, et al: Casticin induces leukemic cell death through apoptosis and mitotic catastrophe. Ann Hematol 88: 743-752, 2009 .

9. Lane SW, Scadden DT and Gilliland DG: The leukemic stem cell niche: current concepts and therapeutic opportunities. Blood 114 1150-1157, 2009.

10. Collins SJ: The HL-60 promyelocytic leukemia cell line: proliferation, differentiation, and cellular oncogene expression. Blood 70: 1233-1244, 1987.

11. Tanaka H, Abe E, Miyaura C, et al: 1 alpha,25-dihydroxyvitamin D3 induces differentiation of human promyelocytic leukemia cells (HL-60) into monocyte-macrophages, but not into granulocytes. Biochem Biophys Res Commun 117: 86-92, 1983.

12. Rovera G, Santoli D and Damsky C: Human promyelocytic leukemia cells in culture differentiate into macrophage-like cells when treated with a phorbol diester. Proc Natl Acad Sci USA 76: 2779-2783, 1979 .

13. Drexler HG and Minowada J: History and classification of human leukemia-lymphoma cell lines. Leuk Lymphoma 31: 305-316, 1998.
14. Solary E, Bertrand R, Kohn KW, et al: Differential induction of apoptosis in undifferentiated and differentiated HL-60 cells by DNA topoisomerase I and II inhibitors. Blood 81: 1359-1368, 1993.

15. Vachon PH: Integrin signaling, cell survival, and anoikis: distinctions, differences, and differentiation. J Signal Transduct 2011: 738137, 2011.

16. Katagiri K, Yokosawa H, Kinashi T, et al: Ubiquitin-proteasome system is involved in induction of LFA-1/ICAM-1-dependent adhesion of HL-60 cells. J Leukoc Biol 65: 778-785, 1999.

17. Lewin G, Maciuk A, Thoret S, et al: Semisynthesis of natural flavones inhibiting tubulin polymerization, from hesperidin. J Nat Prod 73: 702-706, 2010.

18. Fukushima H, Hirano T and Oka K: Staphylococcus aureussuperantigen decreases FKBP51 mRNA expression and cell-response to suppressive efficacy of a glucocorticoid in human peripheral blood mononuclear cells: possible implication of mitogen-activated protein kinase pathways. Eur J Pharmacol 570: 222-228, 2007.

19. Imai M, Kikuchi H,Denda T, et al: Cytotoxic effects of flavonoids against a human colon cancer derived cell line, COLO 201: a potential natural anti-cancer substance. Cancer Lett 276: 74-80, 2009.

20. Yuan B, Ohyama K, Bessho T, et al: Contribution of inducible nitric oxide synthase and cyclooxygenase- 2 to apoptosis induction in smooth chorion trophoblast cells of human fetal membrane tissues. Biochem Biophys Res Commun 341: 822-827, 2006.

21. Yourno J, Burkart P, Mastropaolo W, et al: Monocyte nonspecific esterase. Enzymologic characterization of a neutral serine esterase associated with myeloid cells. J Histochem Cytochem 34: 727-733, 1986.

22. Solary E, Bertrand R and Pommier Y: Apoptosis of human leukemic HL-60 cells induced to differentiate by phorbol ester treatment. Leukemia 8: 792-797, 1994.

23. Murao S, Gemmell MA, Callaham MF, et al: Control of macrophage cell differentiation in human promyelocytic HL-60 leukemia cells by 1,25-dihydroxyvitamin D3 and phorbol-12myristate-13-acetate. Cancer Res 43: 4989-4996, 1983.

24. Imai M, Yuan B, Kikuchi H, et al: Growth inhibition of a human colon carcinoma cell, COLO 201, by a natural product, Vitex agnus-castus fruits extract, in vivo and in vitro. Adv Biol Chem 2: 20-28, 2012.

25. Prieto J, Eklund A and Patarroyo M: Regulated expression of integrins and other adhesion molecules during differentiation of monocytes into macrophages. Cell Immunol 156: 191-211, 1994.

26. Lee SM, Lee YJ, Kim YC, et al: Vascular protective role of vitexicarpin isolated from Vitex rotundifolia in human umbilical vein endothelial cells. Inflammation 35: 584-593, 2012.

27. Hazlehurst LA and Dalton WS: Mechanisms associated with cell adhesion mediated drug resistance (CAM-DR) in hematopoietic malignancies. Cancer Metastasis Rev 20: 43-50, 2001.

28. Li ZW and Dalton WS: Tumor microenvironment and drug resistance in hematologic malignancies. Blood Rev 20: 333-342, 2006.

29. Imai M, Kikuchi H, Yuan B, et al: Enhanced growth inhibitory effect of 5-fluorouracil in combination with Vitex agnus-castus fruits extract against a human colon adenocarcinoma cell line, COLO 201. J Clin Clin Med 6: 14-19, 2011.

30. Zhou Y, Liu YE, Cao J, et al: Vitexins, nature-derived lignan compounds, induce apoptosis and suppress tumor growth. Clin Cancer Res 15: 5161-5169, 2009. 